\title{
Liquid crystalline systems containing Vitamin E TPGS for the controlled transdermal nicotine delivery
}

\author{
Lívia Neves Borgheti-Cardoso', Fabiana Testa Moura de Carvalho Vicentini' ${ }^{1}$, Tais Gratieri², \\ Maria Vitória Lopes Badra Bentley ${ }^{1, *}$
}

\begin{abstract}
${ }^{1}$ Faculty of Pharmaceutical Sciences of Ribeirão Preto, University of São Paulo, Ribeirão Preto, SP, Brazil, ${ }^{2}$ Laboratory of Food Drug and Cosmetics, LTMAC, School of Health Sciences, University of Brasilia, Brasília, DF, Brazil
\end{abstract}

\begin{abstract}
Transdermal nicotine patches have been used in smoking cessation therapy, suggested for the treatment of skin disorders with eosinophilic infiltration and have been found to improve attention performance in patients with Alzheimer's disease and age-associated memory impairment. However, skin irritation with extended patch use is still a problem. The aim of this work was to develop a simple to prepare liquid crystalline system containing vitamin E TPGS that would be able to control nicotine delivery and reduce irritation and sensitization problems. The liquid crystalline phases were macroscopically characterized by visual analysis and examined microscopically under a polarized light microscope. Topical and transdermal delivery of nicotine were investigated in vitro using porcine ear skin mounted on a Franz diffusion cell. Nicotine skin permeation from the developed cubic phase followed zero-order kinetics $(r=0.993)$ and was significantly enhanced after $12 \mathrm{~h}$ when compared to the control formulation (nicotine solution) $(\mathrm{p}<0.05)\left(138.86 \pm 20.44\right.$ and $64.91 \pm 4.06 \mu \mathrm{g} / \mathrm{cm}^{2}$, respectively). Cubic phase was also able to target viable skin layers in comparison to control solution ( $8.18 \pm 1.89$ and $2.63 \pm 2.51 \mu \mathrm{g} / \mathrm{cm}^{2}$, respectively). Further studies to evaluate skin sensitization and irritation are now necessary.
\end{abstract}

Uniterms: Nicotine/transdermal patches. Nicotine/controlled transdermal delivery. Liquid crystalline systems/development. Vitamin E TPGS. Skin irritation/control/in vitro study. Skin irritation/use of transdermal patches.

Adesivos transdérmicos de nicotina são utilizados para cessação de fumar, tratamento de problemas de pele com infiltração de eosinófilos e para melhorar a atenção em pacientes com doença de Alzheimer e enfraquecimento da memória associada à idade. No entanto, a irritação da pele com o uso prolongado dos adesivos ainda é um problema. O objetivo deste trabalho foi desenvolver sistema líquido cristalino (SLC) de preparo simples contendo vitamina E TPGS capaz de controlar a liberação de nicotina e reduzir os problemas de irritação cutânea. Os SLCs foram caracterizados por análise visual e microscopia de luz polarizada. As administrações tópica e transdérmica de nicotina foram investigadas in vitro utilizando pele de orelha de porco em célula de difusão de Franz. A permeação da nicotina veiculada pela fase cúbica desenvolvida seguiu cinética de ordem zero $(r=0,993)$ e foi significativamente maior do que o controle (solução de nicotina) após $12 \mathrm{~h}(\mathrm{p}<0,05)\left(138,86 \pm 20,44\right.$ e $64,91 \pm 4,06 \mu \mathrm{g} / \mathrm{cm}^{2}$, respectivamente). A fase cúbica também promoveu aumento da penetração de nicotina nas camadas viáveis da pele quando comparado ao controle $\left(8,18 \pm 1,89\right.$ e 2,63 $\pm 2,51 \mu \mathrm{g} / \mathrm{cm}^{2}$, respectivamente). Estudos futuros para avaliar a sensibilização e irritação da pele são necessários.

Unitermos: Nicotina/adesivos transdérmicos. Nicotina/liberação controlada. Vitamina E TPGS. Irritação cutânea/controle/estudo in vitro. Irritação cutânea/uso de adesivos transdérmicos.

*Correspondence: M. V. L. B. Bentley. Faculdade de Ciências Farmacêuticas de Ribeirão Preto. Universidade de São Paulo. Av. do Café, s/n, 14040-903 Ribeirão Preto - SP, Brazil. E-mail: vbentley@usp.br 


\section{INTRODUCTION}

Nicotine use in smoking cessation therapy is already well established. It is clinically demonstrated that constant plasma level reduces the craving for smoking. Marketed formulations containing nicotine include chewing gums, transdermal patches, nasal sprays, inhalers and sublingual tablets/lozenges (Stead et al., 2012). Still, adverse effects are related to all of these administration forms: chewing gums may cause dyspepsia and jaw ache; nasal sprays may cause sneezing and coughing and inhalers may also lead to coughing (Karnath, 2002). Nasal and sublingual forms are commonly related to mucosal irritation while both irritation and sensitization reactions are often described as reactions to transdermal patch applications (Levin, 1995; Stead et al., 2012). Such adverse effects can be mild and manageable for short therapy time periods, however, they can decrease patient compliance in longer treatments, which is exactly the main problem with current nicotine replacement therapies.

Recent studies suggest that extended therapies for 24 weeks may be more advantageous than 8 weeks, as it attenuates weight gain, reduces the risk for smoking lapses and increases the likelihood of recovery to abstinence after a lapse (Schnoll et al., 2010; Schnoll, Wileyto, Lerman, 2012). Besides the use in smoking cessation, novel applications for nicotine are suggested. Although its use for symptom control in advanced Parkinson's disease presents inconclusive results (Villafane et al., 2014), chronic transdermal nicotine has been found to improve attention performance in patients with Alzheimer's disease and age-associated memory impairment (White, Levin, 2004). Transdermal nicotine patches have also been suggested for the treatment of skin disorders with eosinophilic infiltration such as Kimura's disease, erythema nodosum and eosinophilic pustular folliculitis (Yoshifuku et al., 2013).

With all these new options and therapies regimen emerging, it is imperative to develop novel formulations able to control delivery and reduce irritation and sensitization problems.

Nicotine is theoretically a good penetrant in the skin; it has low molecular weight and high solubility in both polar and non-polar solvents (Zorin, Kuylenstierna, Thulin, 1999) (Figure 1). However, nicotine is a reactive liquid and a potent solvent that can degrade commonly used patch materials. Resistant polymers, normally allow high nicotine permeability, making drug retention within the system a problem (Davaran et al., 2005).

Liquid crystalline systems can be mainly classified into lamellar, cubic, and hexagonal phases according

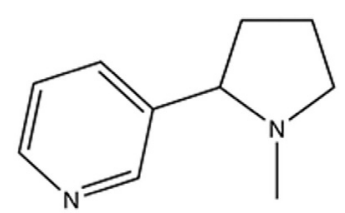

FIGURE 1 - Nicotine chemical structure (MW 162.23).

to their different internal structures. They represent interesting vehicles to be used for skin topical delivery as they can simultaneously protect and improve drug characteristics and interact with the skin favoring drug permeation and tissue recovery. Several studies show that such systems normally do not cause skin irritation after topical application (Esposito et al., 2005; Dong et al., 2006; Lopes, Speretta, Bentley, 2007). Moreover, their highly ordered internal structures offer the potential for slow drug release (Chen, Ma, Gui, 2014). Indeed, liquid crystalline systems have shown to improve the topical/ transdermal delivery of many drugs (Bender et al., 2005, 2008; Peng et al., 2010; Kravchenko, Boyko, Novikova, 2011; Aeinleng et al., 2012).

The dominating internal structure and in vivo performance is notably dependent on the components of the liquid crystalline system and the proportions of each material in the formulation. Tocopheryl polyethylene glycol succinate (TPGS) is a non-ionic water-soluble derivative of vitamin E having an HLB value of 13.2. Chemically, it is D- $\alpha$-tocopheryl polyethylene glycol 1000 succinate possessing a hydrophilic (PEG) head and a lipophilic (phytyl) tail. TPGS is reported to increase poorly absorbed drugs bioavailability due to its solubilizing effect through micelle formation (Aggarwal, Goindi, Mehta, 2012). It has been applied as a solubilizer, an emulsifier, absorption/permeation enhancer, plasticizer, bioadhesive, and as a vehicle in lipid-based drug delivery formulations (Aggarwal, Goindi, Mehta, 2012). Due to its excellent safety profile it has been employed in this study.

Therefore, the aim of this work was to develop a liquid crystalline system containing vitamin E TPGS for the controlled transdermal nicotine delivery.

\section{MATERIAL AND METHODS}

\section{Material}

Nicotine ((-)-nicotine ([-]-1-methyl-2-[3-pyridylpyrrolidine])) was purchased from SIGMA Chemical Co (St Louis, USA). Vitamin E TPGS ( $d$-alpha-tocopheryl polyethylene glycol 1000 succinate) was supplied by Eastman (Kingsport, Tennessee, USA), isopropyl myristate (IPM) from Vetec (Rio de Janeiro, Brazil) and 
propylene glycol (PG) from Synth (Diadema, Brazil). Glacial acid acetic was obtained from Merck (Darmstadt, Germany), diethylamine from Rieder-de-Haen (Seelze, Germany). Sodium phosphate monobasic and sodium phosphate dibasic were from Synth (Diadema, Brazil). Methanol and acetonitrile, both high-performance liquid chromatography (HPLC) grade were from Vetec (Rio de Janeiro, Brazil) and J.T. Baker (USA), respectively. Solutions or mobile phase mixtures were prepared with water purified in a Milli-Q-plus System (Millipore, Bedforte, MA, USA).

\section{Octanol/Water and Octanol/Buffer partition coefficient}

Water saturated with octanol and octanol saturated with water was first obtained by stirring a mixture of water/octanol at ratio $1: 1(\mathrm{v} / \mathrm{v})$ for $1 \mathrm{~h}$ followed by funnel separation. An appropriate amount of nicotine, to obtain a final concentration of $5.0 \mathrm{mg} / \mathrm{mL}$, was added to the water phase in a test tube. The tube was shaken overnight. Thus, the solution was filtered and divided into two fractions. One was quantified by HPLC ( $\mathrm{C} 1$ - before partition). The other was added in oil phase at the ratio $1: 1(\mathrm{v} / \mathrm{v})$ and then they were shaked for one hour. The phases were again separated. Concentrations of nicotine present in the water phase were determined by HPLC (C2 - after partition). The experiment was performed in triplicate. The partition coefficient $\mathrm{K}_{\mathrm{o} / \mathrm{w}}$ was determined according to equation 1 :

$$
\mathrm{K}_{\mathrm{o} / \mathrm{w}}=\frac{\mathrm{C}_{1}-\mathrm{C}_{2}}{\mathrm{C}_{2}}
$$

where, $\mathrm{K}_{\mathrm{o} / \mathrm{w}}$ is octanol/water partition coefficient; $\mathrm{C}_{1}$ is nicotine concentration in the water phase before partition and $\mathrm{C}_{2}$ is nicotine concentration in the water phase after partition.

The determination of partition coefficient oil/buffer followed the same method described for determining the partition coefficient oil/water. The aqueous phase consisted of $0.15 \mathrm{M}$ phosphate buffer $\mathrm{pH}$ 7.2.

\section{Formulation preparation}

Liquid crystalline phases were prepared as previously described by Vicentini et al. (2008). To obtain the systems, mixtures of surfactant (Vitamin E TPGS) and oil (IPM) were prepared in different ratios (3:1, 1:1 and 1:3 $(\mathrm{w} / \mathrm{w}))$, which were diluted with a mixture of water and PG following the same ratio. These systems were shaken in a mixer to obtain a homogeneous formulation, and stored in closed vials for four days to reach equilibrium.
Nicotine was added as a solution to the aqueous phase. The percentage of nicotine in the formulations was $0.25 \%(\mathrm{w} / \mathrm{v})$.

\section{Characterization of the liquid crystal phases}

Liquid crystalline phases were macroscopically characterized by visual analysis and examined microscopically under a polarized light microscope (Axioplan 2 Image Pol microscope, Carl Zeiss, Oberkichen, Germany) after the equilibrium was reached.

\section{Skin}

Porcine ear skin obtained from a local slaughterhouse. Porcine ears were obtained soon after the sacrifice of the animal, before the scalding process. The whole skin was removed from the outer region of the ear, separated from its underlying layer with scissors, dermatomized to $1 \mathrm{~mm}$ thickness and stored frozen at $-20^{\circ} \mathrm{C}$ for a maximum of 1 month before use.

\section{In vitro skin permeation}

The penetration of nicotine in the skin and its percutaneous delivery were evaluated in an in vitro model using porcine ear skin, as previously described (Herai et al., 2007; Gratieri et al., 2014). Briefly, the skin was thawed and mounted in a Franz diffusion cell (diffusion area of $1.77 \mathrm{~cm}^{2}$; Hanson Instruments, Chatsword, CA), with the stratum corneum facing upwards the donor compartment. Receptor compartment was filled with $0.15 \mathrm{M}$ phosphate buffer ( $\mathrm{pH} 7.2)$, and maintained at $37^{\circ} \mathrm{C}$ under constant stirring (300 rpm).

One hundred and fifty milligrams of lamellar or cubic phase containing $0.25 \%$ of nicotine $\left(\mathrm{PG}-\mathrm{H}_{2} \mathrm{O}\right.$ (3:1): VitE TPGS-IPM (3:1) at 20:80 and 50:50, w/w, respectively) were applied on skin surface. One hundred and fifty microliters of nicotine solution $2.5 \mathrm{mg} / \mathrm{mL}$ were used as control. To determine the concentration of permeated nicotine $1 \mathrm{~mL}$ of receptor solution samples were collected at $0,15,30 \mathrm{~min}, 1,2,4,8,12 \mathrm{~h}$ and analyzed by HPLC. At $12 \mathrm{~h}$ post-application of liquid crystals formulation, skin surfaces were carefully washed with distilled water to remove excess formulation. To separate the stratum corneum (SC) from the remaining epidermis (E) and dermis (D), skin sections were subjected to tape stripping. The skin was stripped with 5 pieces of adhesive tape, the first one was discarded, and the others ones containing the $\mathrm{SC}$ were immersed in $2 \mathrm{~mL}$ methanol, vortex stirred for $3 \mathrm{~min}$ and the methanolic phase filtered 
using a $0.45 \mu \mathrm{m}$ membrane. The remaining $[\mathrm{E}+\mathrm{D}]$ were cut in small pieces, vortex for $3 \mathrm{~min}$ in $1 \mathrm{~mL}$ of methanol, and bath sonicated for $30 \mathrm{~min}$. The resulting mixture was then filtered using a $0.45 \mu \mathrm{m}$ membrane, and nicotine was assayed in the filtrate by HPLC as described above. Nicotine recovery from SC and E+D was previously validated and showed error percentages within the limits accepted for validation of methods involving extractive processes $( \pm 15 \%)$.

\section{Kinetic evaluation}

Results were plotted as the mean cumulative amount of drug released/permeated per unit of surface area against time. Different kinetic models were evaluated:

Zero-order model (concentration against time):

$$
Q_{t}=Q_{0}+K_{0} t
$$

Higuchi's model (concentration against square root of time):

$$
Q_{t} / Q_{0}=K_{H} t^{1 / 2}
$$

First order model (logarithm of the concentration against time):

$$
\log \mathrm{Q}_{\mathrm{t}}=\log \mathrm{Q}_{0}+\mathrm{K}_{1} \mathrm{t}
$$

where $Q_{t}$ is the amount diffused $(\mu \mathrm{g})$ at time $t(\mathrm{~h}), Q_{0}$ is the initial amount in the donor compartment $(\mu \mathrm{g}) . K_{0}$ is the zero-order constant $\left(\mu \mathrm{g} \mathrm{h}^{-1}\right), K_{H}$ is the first order constant $\left(\mu \mathrm{g} \mathrm{h}^{-1}\right)$, and $K_{l}$ is the Higuchi's constant $\left(\mu \mathrm{g} \mathrm{h}^{1 / 2}\right)$. The correlation coefficient $(r)$ for each kinetic model was calculated to determine the best fit model.

\section{Analytical analysis}

Nicotine was quantified by an analytical method using a high performance liquid chromatograph (HPLC) Shimadzu LC-10A VP, coupled to a spectrophotometric detector (model SPD-10A VP) and a computer equipped with the chromatographic analysis program Shimadzu LC. Analytical method was based on a previously described methodology (Pereira, Marchetti, Bentley, 2001). Briefly, a reverse-phase column (Lichrospher ${ }^{\circledR} 100$ RP-18 column ( $5 \mu \mathrm{m}$; Merck), equipped with a RP-18 precolumn (Merck) was used as stationary phase, and mobile phase consisted of a mixture of water, methanol, acetonitrile, glacial acid acetic and diethylamine at 93.55:3:2:1:0.45 (v/v/v/v/v). The mobile phase flow rate was $1 \mathrm{~mL} / \mathrm{min}$, the sample injection volume was $50 \mu \mathrm{L}$ and detection was made at $254 \mathrm{~nm}$. The method was validated in terms of linearity, precision, accuracy, specificity/selectivity and limit of quantification, according to current Brazilian legislation (ANVISA, 2003). The regression line equation calculated by the least-squares method was $y=75.42 \mathrm{x}+73$ with a correlation coefficient (r) of 0.9976 . Accuracy and precision were, respectively, $5.51 \%$ and $6.66 \%$. Method limit of quantification (LOQ) was $0.4 \mu \mathrm{g} / \mathrm{mL}$.

\section{Data analyses}

At least four replicates of each transport experiment were performed. Results are presented as mean \pm standard deviation (SD) and expressed in terms of nicotine amount per unit area of skin $\left(\mu \mathrm{g} / \mathrm{cm}^{2}\right)$. Data were statistically analyzed by one way ANOVA, followed by Bonferroni's multiple comparisons t-test. Statistical significance was fixed at $p<0.05$.

\section{RESULTS}

\section{Octanol/Water and Octanol/Buffer partition coefficient}

The partition coefficients were determined according to equation 1 . The octanol/water and octanol/buffer partition coefficient was found to be $3.45( \pm 0.21)$ and 3.51 $( \pm 0.09)$, respectively. This means a $\log P$ approximately of 0.54 .

\section{Preparation and characterization of the liquid crystal phases}

The phase diagram of systems containing Vitamin E TPGS, IPM and $\mathrm{PG}-\mathrm{H}_{2} \mathrm{O}$ in 1:3 ratio is demonstrated in Figure 2. The ternary diagram shows that when the aqueous phase comprises a lower percentage than $30 \%$ the formation of liquid crystalline phase as lamellar, cubic and hexagonal phase are favored. In the range of 30 to $50 \%$ of aqueous phase, cubic phase is obtained when the concentration of Vit E TPGS is greater than or equal to the concentration of IPM, and, when the Vit E TPGS concentration is lower than the IPM concentration liquid crystalline system are not formed, rather forming a simple emulsion. Emulsion is also formed when the percentage of aqueous phase in the system is greater than or equal to $60 \%$.

The association of Vitamin E TPGS, IPM and PG-water in the ratio $1: 1$ and 3:1 has been previously demonstrated (Vicentini et al., 2008). Polarized light microcopy analysis is shown in Figure 3.

After liquid crystalline phases preparation, the effect of nicotine on the systems phase behavior was 


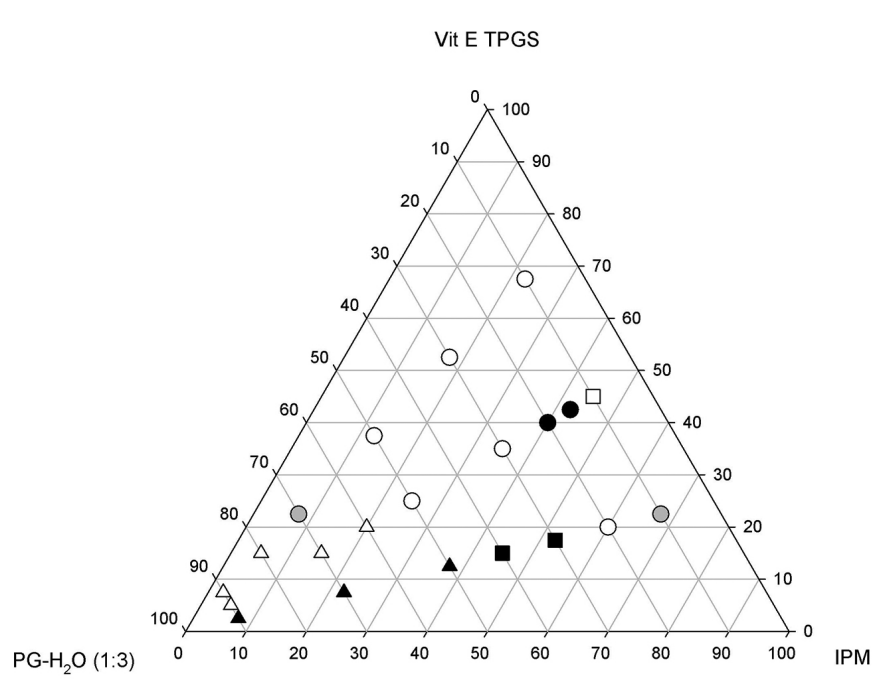

FIGURE 2 - Phase diagram of Vitamin E TPGS/IPM/PG- $\mathrm{H}_{2} \mathrm{O}$ systems at 1:3 ratio. The phase regions are: filled circle hexagonal phase, filled square emulsion, filled triangle unstable emulsion, empty circle cubic phase, empty square lamellar phase, empty triangle isotropic liquid, gray circle cubic phase+water. analyzed. The maximum amount of nicotine that allows the formation of liquid crystalline phases was evaluated by adding nicotine at $0.25 \%, 0.5 \%, 1.0 \%$ and $2.0 \%(\mathrm{w} / \mathrm{v})$ into the most stable systems. The results illustrated in Table I indicated that only at $0.2 \%$ of nicotine it was possible to obtain liquid crystalline phases.

The Figure 4A, 4B and $4 \mathrm{C}$ show the phase diagrams of systems containing the $\mathrm{PG}: \mathrm{H}_{2} \mathrm{O}$ components at $3: 1,1: 1$, $1: 3$ ratios with $0.25 \%(\mathrm{w} / \mathrm{v})$ of nicotine.

Diagrams show that the presence of nicotine can interfere in the formation of liquid crystalline phases. Some cubic and hexagonal phases obtained without nicotine were able to maintain their structure even after drug incorporation, however, many structures were affected by nicotine addiction. On the other hand, lamellar phases structures were maintained.

The formulation composed of Vitamin E TPGS/ IPM/PG-H2O (3:1) at 37.5:7.5:37.5:7.5 w/w/w/w, which was characterized as cubic phase, maintained its structure after drug incorporation. Conversely, the formulation

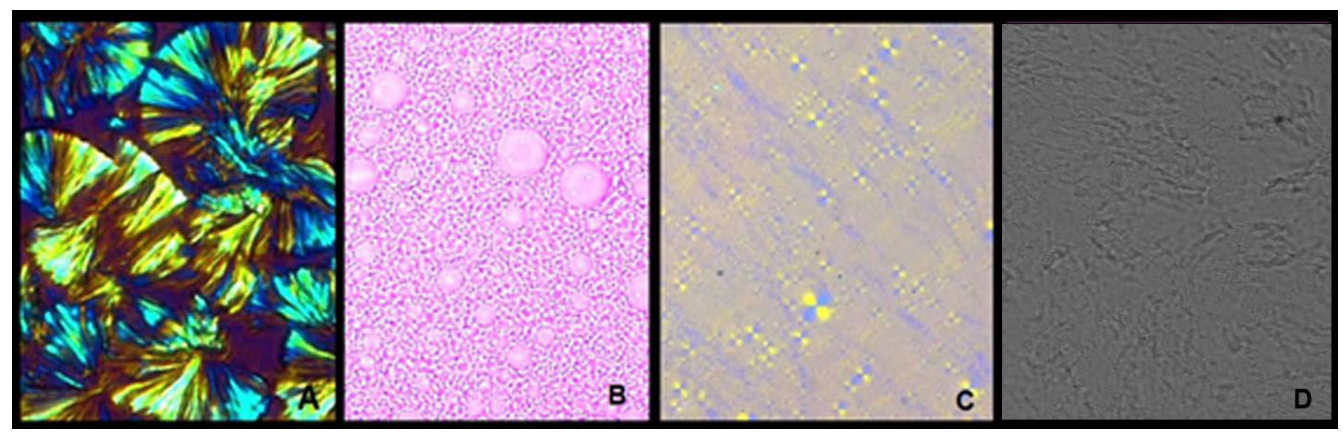

FIGURE 3 - Photomicrographs by polarized light microscopy. (A) Hexagonal phase composed of Vitamin E TPGS/IPM/PG-H $2 \mathrm{O}$ $(3: 1)$ at $67.5: 22.5: 7.5: 2.5 \mathrm{w} / \mathrm{w} / \mathrm{w} / \mathrm{w}$; (B) Unstable emulsion composed of Vitamin E TPGS/IPM/PG-H $2 \mathrm{O}(1: 1)$ at 7.5:22.5:35:35 w/w/w/w, (C) Lamellar phase composed of Vitamin E TPGS/IPM/PG-H2O (1:1) at 60:20:10:10 w/w/w/w and (D) Cubic phase (cubic phase+water) composed of Vitamin E TPGS/IPM/PG-H2O (1:3) at 22.5:67.5:2.5:7.5 w/w/w/w. Increase 200X.

TABLE I - Structural identification by visual analyses and polarized light microscopy of different formulations

\begin{tabular}{|c|c|c|c|c|c|}
\hline \multirow{2}{*}{ System } & \multicolumn{5}{|c|}{ Nicotine concentration (w/v \%) } \\
\hline & 0.0 & 0.25 & 0.5 & 1.0 & 2.0 \\
\hline 5 (PG: $\left.\mathrm{H}_{2} \mathrm{O}-3: 1\right): 5$ (Vit E: IPM-3:1) & Cubic Phase & Cubic Phase & - & - & - \\
\hline 1 (PG:H $\left.\mathrm{H}_{2} \mathrm{O}-1: 1\right)$ : 9 (Vit E: IPM-3:1) & Lamellar Phase & - & - & - & - \\
\hline 1(PG:H $\left.\mathrm{H}_{2} \mathrm{O}-3: 1\right): 9$ (Vit E: IPM-3:1) & $\begin{array}{l}\text { Hexagonal + } \\
\text { Cubic Phase }\end{array}$ & - & - & - & - \\
\hline 4.5 (PG: $\left.\mathrm{H}_{2} \mathrm{O}-3: 1\right): 5.5$ (Vit E: IPM-1:3) & Emulsion & - & - & - & - \\
\hline $2\left(\mathrm{PG}: \mathrm{H}_{2} \mathrm{O}-3: 1\right): 8$ (Vit E: IPM-3:1) & $\begin{array}{l}\text { Hexagonal + } \\
\text { Cubic Phase }\end{array}$ & Lamellar Phase & $\begin{array}{l}\text { Isotropic } \\
\text { Liquid }\end{array}$ & $\begin{array}{l}\text { Isotropic } \\
\text { Liquid }\end{array}$ & $\begin{array}{c}\text { Isotropic } \\
\text { Liquid }\end{array}$ \\
\hline $1\left(\mathrm{PG}: \mathrm{H}_{2} \mathrm{O}-1: 3\right)$ : & Lamellar Phase & - & $\begin{array}{l}\text { Isotropic } \\
\text { Liquid }\end{array}$ & $\begin{array}{l}\text { Isotropic } \\
\text { Liquid }\end{array}$ & $\begin{array}{c}\text { Isotropic } \\
\text { Liquid }\end{array}$ \\
\hline
\end{tabular}

PG: propylene glycol; Vit E: Vitamin E TPGS; IPM: isopropyl myristate; (-): did not form liquid crystalline phase. 
A

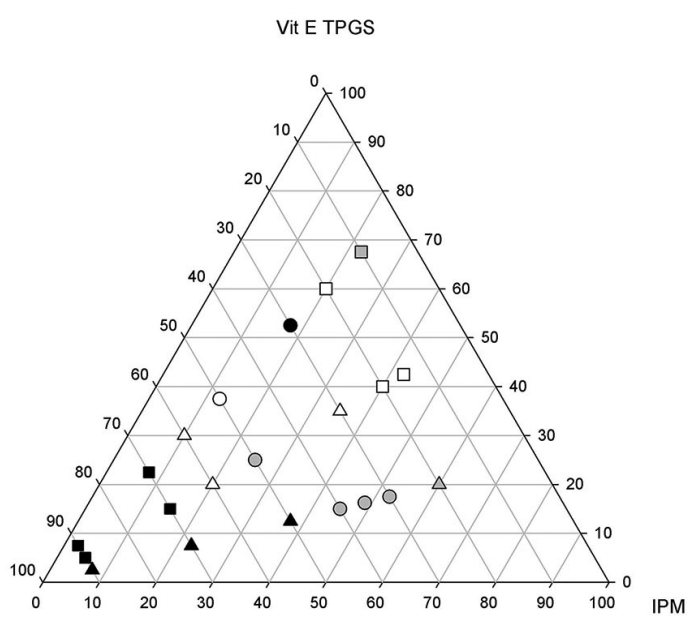

$\mathrm{PG}-\mathrm{H}_{2} \mathrm{O}(3: 1)$

B

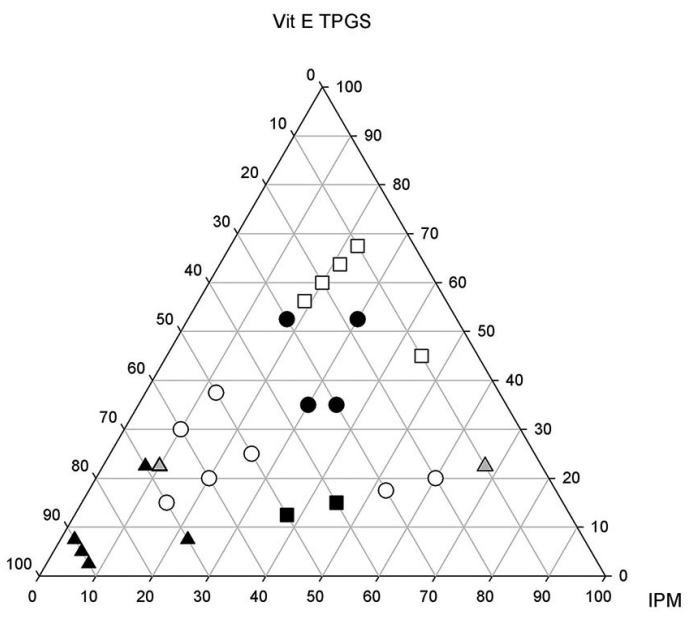

C

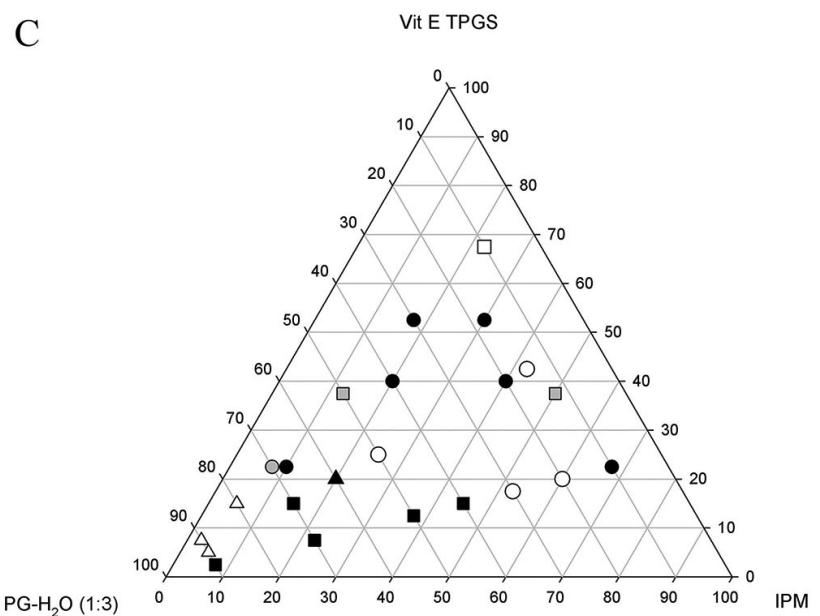

$\mathrm{PG}-\mathrm{H}_{2} \mathrm{O}(1: 3)$

FIGURE 4 - Phase diagrams of Vitamin E TPGS/IPM/PG- $\mathrm{H}_{2} \mathrm{O}$ systems at (A) 3:1, (B) 1:1 and (C) 1:3 ratios with $0.25 \%(\mathrm{w} / \mathrm{v})$ of nicotine. The phase regions are: filled circle birrefringence, filled square emulsion, filled triangle unstable emulsion, empty circle cubic phase, empty square lamellar phase, empty triangle isotropic liquid, gray circle cubic phase+water, gray square cubic phase+hexagonal phase, gray triangle hexagonal phase+water. composed of Vitamin E TPGS/IPM/PG-H2O (3:1) at 15:5:60:20 w/w/w/w was characterized as cubic + hexagonal phase and turned into a lamellar phase internal structure upon drug incorporation. The influence of these liquid crystalline phases on nicotine permeation through the skin was evaluated.

\section{In vitro skin penetration and percutaneous delivery}

Cubic phase system significantly enhanced nicotine skin penetration after $12 \mathrm{~h}$, compared to the control formulation (nicotine solution) $(\mathrm{p}<0.05)$.

The cumulative amount of permeated nicotine for $12 \mathrm{~h}$ was $138.86 \pm 20.44 \mu \mathrm{g} / \mathrm{cm}^{2}(65.54 \%$ of the initial content) and $64.91 \pm 4.06 \mu \mathrm{g} / \mathrm{cm}^{2}(30.64 \%$ of the initial content) when, respectively, cubic phase and control solution were applied.

Even though lamellar phase system promoted a faster permeation at first hours, there was no significant difference in the total drug amount permeated when the lamellar system was applied $\left(153.47 \pm 14.22 \mu \mathrm{g} / \mathrm{cm}^{2}\right.$, representing $72.44 \%$ of the initial content) compared to the cubic phase $(p>0.05)$ (Figure 5). Cubic phase system was the only formulation studied able to control nicotine permeation following a zero order kinetics $(r=0.993)$, while drug permeation from the lamellar phase system and control solution followed Higuchi kinetics $(r=0.972$ and 0.994 , respectively).

Incorporation of nicotine in the lamellar phase promoted greater drug penetration in the SC

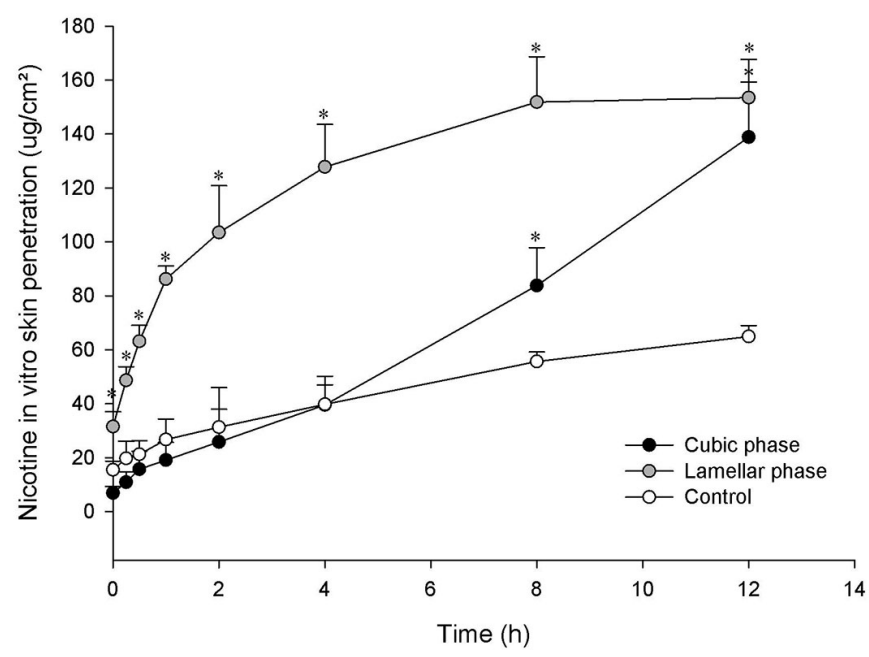

FIGURE 5 - Time-course of the in vitro skin penetration of nicotine incorporated into different formulations. The number of replicates is 4 per experimental group. ${ }^{*} \mathrm{p}<0.05$ compared to control. 
$\left(5.87 \pm 2.37 \mu \mathrm{g} / \mathrm{cm}^{2}\right)$ and $[\mathrm{E}+\mathrm{D}]\left(13.82 \pm 0.70 \mu \mathrm{g} / \mathrm{cm}^{2}\right)$ compared to the control $\left(1.17 \pm 0.26 \mu \mathrm{g} / \mathrm{cm}^{2}\right.$ and $2.63 \pm 2.51 \mu \mathrm{g} / \mathrm{cm}^{2}$, respectively) $(\mathrm{p}<0.05)$, while the cubic phase was able to target [E+D] $\left(8.18 \pm 1.89 \mu \mathrm{g} / \mathrm{cm}^{2}\right)$ compared to the control $(\mathrm{p}<0.05)$, maintaining similar SC amounts $\left(1.34 \pm 0.41 \mu \mathrm{g} / \mathrm{cm}^{2}\right)$ than the control solution $(\mathrm{p}>0.05)$ (Figure 6).

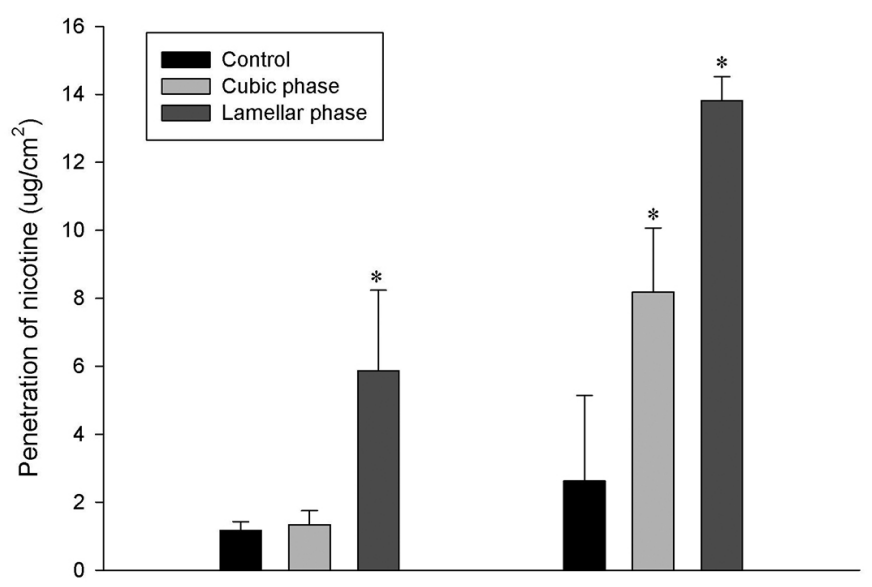

FIGURE 6 - In vitro skin penetration of nicotine at $12 \mathrm{~h}$ following topical application using cubic and lamellar phase systems containing $375 \mu \mathrm{g}$ of nicotine or a control solution $(2.5 \mathrm{mg} / \mathrm{mL})$. SC: stratum corneum, [E+D]: epidermis (without SC) plus dermis. Results are represented be means \pm S.D. $(n=4)$. $* \mathrm{p}<0.05$ compared to control.

\section{DISCUSSION}

In the current study, the potential application of cubic and lamellar phases of Vitamin E TPGS, IPM, PG and water as a topical delivery system of nicotine was demonstrated. Since Vitamin E TPGS has a lipophilic alkyl tail (polyethylene glycol) and a hydrophilic polar head portion (tocopherol succinate), it appears to be a promising molecule to obtain liquid crystalline systems (Aggarwal, Goindi, Mehta, 2012).

The diagrams presented in Figure 4 show that the presence of nicotine can interfere with the formation of some liquid crystalline phases. Several authors also noticed changes in the liquid crystalline phase due to the addition of drugs and solvents. The characteristics of the additives determine their location at the polar or apolar domains of the systems, which can affect the molecular packing and promote phase transition. Hydrophilic or charged compounds favor the phase change from cubic to lamellar phase, while non-polar compounds favor cubic and hexagonal phase formation (Kumar et al., 2004; Liu et al., 2013; Engstrom, Engstrom, 1992). The addition of nicotine to the formulation composed of Vitamin E TPGS/IPM/PG-H2O (3:1) at 15:5:60:20 $\mathrm{w} / \mathrm{w} / \mathrm{w} / \mathrm{w}$ favored the change from cubic to lamellar phase corroborating the literature (Liu et al., 2013; Engstrom, Engstrom, 1992). On the other hand, the presence of nicotine at $0.25 \%$ did not affect the liquid crystalline system formed by Vitamin E TPGS/IPM/ PG-H2O (3:1) at 37.5:7.5:37.5:7.5 w/w/w/w, which maintained its cubic phase. Therefore, the presence and amount of all components influence molecular packing parameters, determining the type of liquid crystalline system formed. Hence, it is important to characterize the formulation because liquid crystalline structure may influence the drug release (Guo et al., 2010).

To evaluate if liquid crystalline phase of Vitamin $\mathrm{E}$ TPGS, IPM, PG and water can act as topical/transdermal system for the controlled delivery of nicotine, skin percutaneous delivery of nicotine incorporated in the cubic and lamellar phase were studied in comparison to a control solution. Incorporation of nicotine in the cubic phase promoted increase in the nicotine permeation compared with the control and followed a zero-order kinetics, meaning that the cubic phase formulation was able to control nicotine delivery for $12 \mathrm{~h}$. Lamellar phase system was able to promote a faster permeation at first hours. Nonetheless, the total drug amount permeated from either lamellar or cubic phases after $12 \mathrm{~h}$ did not present significant statistical difference $(p>0.05)$. Cubic phase system was also able to target the viable epidermis $[\mathrm{E}+\mathrm{D}]$, but did not influence the penetration through the SC compared with the control solution. Several studies showed that liquid crystalline phases are greater for topical delivery compared with solutions (Lim et al., 2014, Bender et al., 2008) corroborating with the present results. Still, cubic phase penetration pathways into the skin have been poorly studied. Bender et al. (2008) proposed that cubic phase penetrates into skin mainly by micro-fissures, from which hydrophilic compounds diffuse into the surrounding intercellular lipid matrix being a source for sustained release (Bender et al., 2008). In the present study, as shown above, the incorporation of nicotine in both lamellar and cubic phases enhanced the in vitro permeation and penetration in the skin. A possible explanation may be the action of Vitamin E-TPGS and IPM as penetration enhancers (Guo et al., 2013; Aggarwal, Goindi, Mehta, 2012; Engelbrecht et al., 2012). Indeed, it has been reported that Vitamin $\mathrm{E}$ acts as a permeation enhancer by intercalating within the lipid bilayer region of the SC, promoting changes of membrane permeability (Trivedi, Krill, Fort, 1995), while IPM acts as penetration enhancer by introducing phase separation and perturbing the multilamellar lipid assembly (Engelbrecht et al., 2012). 
Besides the contribution of liquid crystalline structure in increasing the skin uptake of drugs, it is also important to consider the different performances of each particular structure. The differences observed in the in vitro skin penetration of nicotine incorporated in the cubic and lamellar phases may be related with the differences of the percentages constituents and can be explained by the partition coefficient. The octanol/water (3.45) or octanol/buffer (3.51) partition coefficient indicated that the nicotine, a hydrophilic drug, has great preference for water medium, so the cubic phase that have more water content was able to better control nicotine delivery. The lamellar phase, which has a higher percentage of oil phase, promoted a higher flux of nicotine through the skin at first hours, but not in a controlled fashion, reflected by the Higushi kinetics model. Accordingly, Carr, Corish, Corrigan (1997) studied the in vitro nicotine release from lyotropic liquid crystal gels obtained from Myverol. They observed that water increase in the vehicle would lead to an increased release flux, increasing its partitioning into the membrane (Carr, Corish, Corrigan, 1997).

As stated above, nicotine is a good penetrant in the skin; it has low molecular weight and high solubility in both polar and non-polar solvents (Zorin, Kuylenstierna, Thulin, 1999), therefore, high permeation percentages are expected. The real challenge is to develop a stable, biocompatible formulation that is able to control drug delivery in a predictable fashion.

Delivery rates may vary enormously depending on formulation components. Mucoadhesive patches composed of xantham gum and Carbopol 934-based showed to release up to $98 \%$ and $39 \%$, respectively, after $10 \mathrm{~h}$ (Abu-Huwaij et al., 2011).

In vitro comparative studies of two marketed transdermal nicotine delivery systems (Nicopatch ${ }^{\circledR}$ and Nicorette ${ }^{\circledR}$ ) demonstrated that the cumulative amount of permeated nicotine was $709 \pm 56 \mu \mathrm{g} . \mathrm{cm}^{-2}$ ( $40 \%$ of the initial surface area content) at $24 \mathrm{~h}$ for Nicopatch and for Nicorette, it was $501 \pm 39 \mu \mathrm{g} \mathrm{cm}^{-2}$ ( $60 \%$ of the initial surface area content) at $16 \mathrm{~h}$ and $717 \pm 58 \mu \mathrm{g} . \mathrm{cm}^{-2}(86 \%)$ at $24 \mathrm{~h}$ (Olivier, Rabouan, Couet, 2003). Correspondingly, transdermal nicotine patches available in the Brazilian market, including a rate-controlling membrane device $\left(15 \mathrm{~cm}^{2}\right.$ of patch size containing $78 \mathrm{mg}$ of drug) and a polymeric matrix device (20 $\mathrm{cm}^{2}$ of patch size containing $35 \mathrm{mg}$ of drug) showed permeation rates of $41.7 \pm 1.2 \mu \mathrm{g} . \mathrm{cm}^{-2} \cdot \mathrm{h}^{-1}$ and $38.3 \pm 3.6 \mu \mathrm{g} . \mathrm{cm}^{-2} . \mathrm{h}^{-1}$, respectively (Ruela et al., 2013). Vitamin E TGPS cubic phase system developed promoted a lower cumulative amount of permeated nicotine per $\mathrm{cm}^{2}$ and lower release rate $\left(138.86 \pm 20.44 \mu \mathrm{g} . \mathrm{cm}^{-2}\right.$ after $12 \mathrm{~h}$ and $\left.10.48 \mu \mathrm{g} . \mathrm{cm}^{-2} \cdot \mathrm{h}^{-1}\right)$ compared with marketed patches, but comparable released percentage amounts $(65.54 \%$ of the initial content). Such differences are obviously related to the applied drug doses. Even though the cubic phase system have a drug loading limitation, as evidenced by the results reported in Table I, the developed cubic phase system can be easily applied to larger skin areas, while patches are applied from $10 \mathrm{~cm}^{2}$ to $20 \mathrm{~cm}^{2}$. Being the maximal applied area normally $20 \mathrm{~cm}^{2}$.

Hence, the developed cubic phase system was able to achieve the task of controlling drug delivery. Skin irritation and sensitization studies to attest formulation safety are now necessary.

\section{CONCLUSION}

Developed Vitamin E TGPS cubic phase system is a simple formulation, formed with just the mixture of emulsifier, oil phase and water, which make its fabrication exceptionally easy, low cost, without the need for sophisticated equipment for preparation. The formulation was able to control drug delivery following zero-order kinetics. It is an interesting drug delivery system with potential to be used for extended smoking cessation therapy or other situations where systemic nicotine delivery is indicated.

\section{ACKNOWLEDGEMENTS} Brazil.

This work was supported by FAPESP and CNPq,

\section{REFERENCES}

ABU-HUWAIJ, R.; OBAIDAT, R.M.; SWEIDAN, K.; ALHIARI, Y. Formulation and in vitro evaluation of Xanthan Gum or Carbopol 934-based mucoadhesive patches, loaded with nicotine. AAPS Pharmscitech., v.12, n.1, p.21-27, 2011.

AEINLENG, N.; SONGKRO, S.; NOIPHA, K.; SRICHANA T. Physicochemical performances of indomethacin in cholesteryl cetyl carbonate liquid crystal as a transdermal dosage. AAPS Pharmscitech., v.13, n.2, p.513-521, 2012.

AGGARWAL, N.; GOINDI, S.; MEHTA, S.D. Preparation and evaluation of dermal delivery system of griseofulvin containing vitamin E-TPGS as penetration enhancer. AAPS Pharmscitech., v.13, n.1, p.67-74, 2012. 
AGÊNCIA NACIONAL DE VIGILÂNCIA SANITÁRIA. ANVISA. Resolução RE n.899, de 29 de maio de 2003. Determina a publicação do "Guia para validação de métodos analíticos e bioanalíticos". Available at: <http://portal. anvisa.gov.br/wps/wcm/connect/4983b0004745975da005 f43fbc4c6735/RE_899_2003_Determina+a+publica\%C3 $\% \mathrm{~A} 7 \% \mathrm{C} 3 \% \mathrm{~A} 3 \mathrm{o}+\mathrm{do}+$ Guia + para + valida $\% \mathrm{C} 3 \% \mathrm{~A} 7 \% \mathrm{C} 3 \%$ $\mathrm{A} 3 \mathrm{o}+\mathrm{de}+\mathrm{m} \% \mathrm{C} 3 \% \mathrm{~A} 9$ todos + anal $\% \mathrm{C} 3 \%$ ADticos $+\mathrm{e}+$ bioa nal $\%$ C $3 \%$ ADticos.pdf?MOD $=$ AJPERES $>$. Accessed on: 20 Aug. 2015.

BENDER, J.; SIMONSSON, C.; SMEDH, M.; ENGSTROM, S.; ERICSON, M.B. Lipid cubic phases in topical drug delivery: visualization of skin distribution using two-photon microscopy. J. Control. Release, v.129, n.3, p.163-169, 2008.

BENDER, J.; ERICSON, M.B.; MERCLIN, N.; IANI, V.; ROSEN, A.; ENGSTROM, S. Lipid cubic phases for improved topical drug delivery in photodynamic therapy. J. Control. Release, v.106, n.3, p.350-360, 2005.

CARR, M.G.; CORISH, J.; CORRIGAN, O.I. Drug delivery from a liquid crystalline base across Visking and human stratum corneum. Int. J. Pharm., v.157, n.1, p.35-42, 1997.

CHEN, Y.L.; MA, P.Y.; GUI, S. Cubic and hexagonal liquid crystals as drug delivery systems. Biomed Res. Int., v.2014, art.815981, p.1-12, 2014.

DAVARAN, S.; RASHIDI, M.R.; KHANDAGHI, R.; HASHEMI, M. Development of a novel prolonged-release nicotine transdermal patch. Pharmacol. Res., v.51, n.3, p.233-237, 2005.

DONG, Y.D.; LARSON, I.; HANLEY, T.; BOYD, B.J. Bulk and dispersed aqueous phase behavior of phytantriol: Effect of vitamin E acetate and F127 polymer on liquid crystal nanostructure. Langmuir, v.22, p.9512-9518, 2006.

ENGELBRECHT, T.N.; DEMÉ, B.; DOBNER, B.; NEUBERT, R.H.H. Study of the influence of the penetration enhancer isopropyl myristate on the nanostructure of stratum corneum lipid model membranes using neutron diffraction and deuterium labelling. Skin Pharmacol. Physiol., v.25, n.4, p.200-207, 2012.

ENGSTROM, S.; ENGSTROM, L. Phase behaviour of the lidocaine-monoolein-water system. Int. J. Pharm., v.79, n.1/3, p.113-122, 1992.
ESPOSITO, E.; CORTESI, R.; DRECHSLER, M.; PACCAMICCIO, L.; MARIANI, P.; CONTADO, C. Cubosome dispersions as delivery systems for percutaneous administration of indomethacin. Pharm. Res., v.22, n.12, p.2163-2173, 2005.

GRATIERI, T.; PUJOL-BELLO, E.; GELFUSO, G.M.; SOUZA, J.G.; LOPEZ, R.F.V.; KALIA, Y.N. Iontophoretic transport kinetics of ketorolac in vitro and in vivo: demonstrating local enhanced topical drug delivery to muscle. Eur. J. Pharm. Biopharm., v.86, n.2, p.219-226, 2014.

GUO, Y.; LUO, J.; TAN, S.; OTIENO, B.O.; ZHANG, Z. The applications of vitamin E TPGS in drug delivery. Eur. $J$. Pharm. Sci., v.49, n.2, p.175-186, 2013.

GUO, C.; WANG, J.; CAO, F.; LEE, R.J.; ZHAI, G. 2010. Lyotropic liquid crystal systems in drug delivery. Drug Discov. Today. v.15, n.23/24, p.1032-1040, 2010.

HERAI, H.; GRATIERI, T.; THOMAZINE, J.A.; BENTLEY, M.V.L.B.; LOPEZ, R.F.V. Doxorubicin skin penetration from monoolein-containing propylene glycol formulations. Int. J. Pharm., v.329, n.1/2, p.88-93, 2007.

KARNATH, B. Smoking cessation. Am. J. Med., v.112, p.399405, 2002.

KRAVCHENKO, I.A.; BOYKO, Y.A.; NOVIKOVA, N.A. Thermotropic liquid crystal - potential enhancer of transdermal delivery of 1,4-benzodiazepines. Eur. Neuropsychopharm., v.21, p.S146-S146, 2011.

KUMAR, M.K.; SHAH, M.H.; KETKAR, A.; MAHADIK, K.R.; PARADKAR, A. Effect of drug solubility and different excipients on floating behavior and release from glyceryl monooleate matrices. Int. J. Pharm., v.272, n.1/2, p.151-160, 2004.

LEVIN, E.D. Nicotine skin patch treatment and adverse reactions - skin irritation, skin sensitization, and nicotine as a hapten - reply. J. Clin. Psychopharm., v.15, p.146-146, 1995.

LIM, D.G.; JEONG, W-W.; KIM, N.A.; LIM, J.Y.; LEE, S-H.; SHIM, W.S.; KANG, N-G; JEONG, S.H. Effect of the glyceryl monooleate-based lyotropic phases on skin permeation using in vitro diffusion and skin imaging. Asian J. Pharm. Sci., v.9, n.6, p.324-329, 2014. 
LIU, Q.; DONG, Y.D.; HANLEY, T.L.; BOYD, B.J. Sensitivity of nanostructure in charged cubosomes to phase changes triggered by ionic species in solution. Langmuir, v.29, p.14265-14273, 2013.

LOPES, L.B.; SPERETTA, F.F.F.; BENTLEY, V.M.L.B. Enhancement of skin penetration of vitamin K using monoolein-based liquid crystalline systems. Eur. J. Pharm. Sci., v.32, n.3, p.209-215, 2007.

OLIVIER, J.C.; RABOUAN, S.; COUET, W. In vitro comparative studies of two marketed transdermal nicotine delivery systems: Nicopatch (R) and Nicorette (R). Int. J. Pharm., v.252, p.133-140, 2003.

PENG, X.S.; WEN, X.G.; PAN, X.; WANG, R.C.; CHEN, B.; WU, C.B. Design and in vitro evaluation of capsaicin transdermal controlled release cubic phase gels. AAPS Pharmscitech., v.11, n.3, p.1405-1410, 2010.

PEREIRA, G.R.; MARCHETTI, J.M.; BENTLEY, M.V.L.B. A simple and rapid method for nicotine assay by hplc from cutaneous microdialysis samples. Anal. Lett., v.34, p.16691676, 2001.

RUELA, A.L.M.; FIGUEIREDO, E.C.; PERISSINATO, A.G.; LIMA, A.C.Z.; ARAUJO, M.B.; PEREIRA, G.R. In vitro evaluation of transdermal nicotine delivery systems commercially available in Brazil. Braz. J. Pharm. Sci., v.49, n.3, p.579-588, 2013.

SCHNOLL, R.A.; WILEYTO, E.P.; LERMAN, C. Extended duration therapy with transdermal nicotine may attenuate weight gain following smoking cessation. Addict Behav., v.37, n.4, p.565-568, 2012.

SCHNOLL, R.A.; PATTERSON, F.; WILEYTO, E.P.; HEITJAN, D.F.; SHIELDS, A.E.; ASCH, D.A. Effectiveness of extended-duration transdermal nicotine therapy: a randomized trial. Ann. Intern. Med., v.152, n.3, p.144-151, 2010 .
STEAD, L.F.; PERERA, R.; BULLEN, C.; MANT, D.; HARTMANN-BOYCE, J.C.; CAHILL, K.; LANCASTER, T. Nicotine replacement therapy for smoking cessation. Cochrane Database Syst. Rev., v.11, art.CD000146, p.1264, 2012.

TRIVEDI, J.S.; KRILL, S.L.; FORT, J.J. Vitamin E as a human skin penetration enhancer. Eur. J. Pharm. Sci., v.3, n.4, p.241-243, 1995.

VICENTINI, F.T.M.C.; CASAGRANDE, R.; VERRI, W.A.; GEORGETTI, S.R.; BENTLEY, M.V.L.B.; FONSECA, M.J.V. Quercetin in lyotropic liquid crystalline formulations: physical, chemical and functional stability. AAPS Pharmscitech., v.9, n.2, p.591-596, 2008.

VILLAFANE, G.; THIRIEZ, C.; KERSCHEN, P.; ITTI, E.; FENELON, G.; CESARO, P. Efficacy of transdermal nicotine, in advanced Parkinson's disease. a controlled open-label study in 40 patients randomised in two parallel groups. Movement Disord., v.29, p.S272-S273, 2014.

WHITE, H.K.; LEVIN, E.D. Chronic transdermal nicotine patch treatment effects on cognitive performance in ageassociated memory impairment. Psychopharmacol., v.171, n.4, p.465-471, 2004.

YOSHIFUKU, A.; HIGASHI, Y.; MATSUSHITA, S.; KAWAI, K.; KANEKURA, T. Transdermal nicotine patches for eosinophilic pustular folliculitis. J. Dermatol., v.40, n.9, p.711-714, 2013.

ZORIN, S.; KUYLENSTIERNA, F.; THULIN, H. In vitro test of nicotine's permeability through human skin. Risk evaluation and safety aspects. Ann. Occup. Hyg., v.43, n.6, p.405-413, 1999.

Received for publication on $17^{\text {th }}$ December 2014 Accepted for publication on $28^{\text {th }}$ August 2015 